\title{
The Distribution of Wages in Transition
}

\section{Countries}

Andrew Newell

March 2001 


\title{
The Distribution of Wages in Transition Countries
}

\author{
Andrew Newell \\ University of Sussex and IZA, Bonn \\ Discussion Paper No. 267 \\ March 2001 \\ IZA \\ P.O. Box 7240 \\ D-53072 Bonn \\ Germany \\ Tel.: +49-228-3894-0 \\ Fax: +49-228-3894-210 \\ Email: iza@iza.org
}

This Discussion Paper is issued within the framework of IZA's research area Labor Markets in Transition. Any opinions expressed here are those of the author(s) and not those of the institute. Research disseminated by IZA may include views on policy, but the institute itself takes no institutional policy positions.

The Institute for the Study of Labor (IZA) in Bonn is a local and virtual international research center and a place of communication between science, politics and business. IZA is an independent, nonprofit limited liability company (Gesellschaft mit beschränkter Haftung) supported by the Deutsche Post AG. The center is associated with the University of Bonn and offers a stimulating research environment through its research networks, research support, and visitors and doctoral programs. IZA engages in (i) original and internationally competitive research in all fields of labor economics, (ii) development of policy concepts, and (iii) dissemination of research results and concepts to the interested public. The current research program deals with (1) mobility and flexibility of labor markets, (2) internationalization of labor markets and European integration, (3) the welfare state and labor markets, (4) labor markets in transition, (5) the future of work, (6) project evaluation and (7) general labor economics.

IZA Discussion Papers often represent preliminary work and are circulated to encourage discussion. Citation of such a paper should account for its provisional character. 
IZA Discussion Paper No. 267

March 2001

\section{ABSTRACT \\ The Distribution of Wages in Transition Countries*}

This paper seeks to document and analyse changes in the distribution of wages and employment in the transition countries since the collapse of communism. Most countries experienced an increase in wage inequality during the initial shock of the transition. Proximate causes of this increase seem to be sectoral shifts in employment and increasing inter-industry wage differentials.

In Eastern Europe, where economic growth has restarted, there have been further increases in income inequality. These changes are arguably the best guide to future trends in the wage distribution. Taking the case of Poland, rising inequality appears to be entirely accounted for by an increased incidence of workless households. This rise in workless households derives from two phenomena: rising participation in post-compulsory education and earlier retirement. Also in Poland, though there is no change in hourly wage inequality, structural change has had clear impacts of the distribution of wages with increased wage premia to education, to growing sectors and geographically advantaged regions in the economy and to senior occupations.

JEL Classification: J31, P2

Keywords: Wage distribution, inequality, transition, and structural change

Andrew Newell

School of Social Sciences

University of Sussex

Brighton, BN1 9SN

UK

Tel: $+44(0) 1273606755$

Fax: $+44(0) 1273673563$

Email: A.T.Newell@sussex.ac.uk

\footnotetext{
* I thank participants at an IZA workshop on 'International integration and European labour markets' in December 2000, for comments on an earlier draft, especially, Lilo Locher and Michael Burda. Also thanks to participants at the Sussex Research In Progress seminar in February 2001.
} 


\section{1: Introduction.}

This paper seeks to document and analyse the stylised facts of what happened to the distribution of wages and employment in the transition countries since the collapse of communism. To do this, it is useful to split the 1990s roughly into an 'initial shock' period and, for some countries, a period of post-shock revival.

In section 2 I discuss aggregate trends, showing how real wages and GDP have tended to move together, whereas employment, though contracting, has not tracked GDP movements very closely. The main reason for the latter phenomenon is likely to be the well-documented tendency to labour hoarding, or perhaps better understood as labour retention, especially in the former Soviet countries. I also document a rise in income inequality that is fairly universal in the initial shock period of the transition. In countries where economic growth has revived, though, inequality seems also to be continuing to increase. This is also reflected by (and perhaps partially caused by) increased variation in wages across industries. By contrast, wage inequality have tended to stagnate since the initial shock in countries where GDP has also stagnated.

Simultaneously there has been a great deal of structural change. Section 3 discusses the key features of changes in employment and wages by industry and occupation. Production industry employment has generally shrunk, as has agricultural employment except where agriculture has been used as the employer of last resort. Agricultural wages have fallen almost everywhere, sometimes dramatically. Service sector employment and wages have risen in most countries.

In section 4, I switch to a detailed study of the emerging wage distribution in Poland, using Polish labour Force data. The two issues on which I focus are:

1. Analysing the rise in labour income inequality over the later part of the 1990s, in particular the contribution of changes in labour market participation.

2. Analysing the impact of sectoral shifts and privatisation on the wage distribution.

I find the late 1990s rise in labour income inequality in Poland is accounted for by a rise in the proportion of workless households. The rise in workless households derives from two phenomena: rising participation in post-compulsory 
education and with earlier retirement. Also in Poland, though there is no change in hourly wage inequality, structural change has had clear impacts of the distribution of wages with increased wage premia to education, to growing sectors and geographically advantaged regions in the economy and to senior occupations. 


\section{2: Movements in wages, employment and income inequality.}

2.1. Cross-country patterns in employment and real wages.

In general, the economies of Eastern Europe hit their output troughs no later than 1993, and most have grown quite consistently since. The exceptions are Bulgaria and Romania, where little economic growth has taken place since 1993. In contrast, the general picture of the former Soviet economies is of much deeper output troughs occurring significantly later than 1993, if at all. Only a few of these countries, the Baltic states, Belarus and slow-reforming, raw material rich Uzbekistan showed signs of economic recovery in the late 1990s.

Across the transition countries wages and output have tended to move together. To illustrate aggregate movements in real wages, Chart 1 plots changes in real consumption wages against GDP changes 1989-1998. The recovery in most of Eastern Europe is clear. Like real wages and output, employment fell almost everywhere, but there is little sign of a cross-country Okun relationship, see Chart 2 where changes in employment are plotted against changes in output 1989-1998. Chart 2 reminds us of two things. First, labour hoarding has been much greater in the former Soviet countries. With the exceptions of Romania and Bulgaria, the East European states are the only countries to have recorded larger proportional falls in employment than in output. Perhaps labour hoarding is the wrong expression, since it suggests that only the employers have an interest in maintaining a job. As is well known, part of the reason for the maintenance of jobs in the face of output collapses in the transition countries lies with social benefits provided by enterprises. Secondly, the data imply that productivity and GDP tended to move together across countries. Therefore the output revivals in Eastern Europe are also revivals of productivity growth.

\subsection{The path of inequality.}

Many commentators have suggested that an increase in income inequality will be a durable, long term feature of the transition process, see for instance, Milanovic (1999), Aghion and Commander (1999) and Munich, Svejnar and Terrell, (1999). The reason for 
this prediction was a perception that wages were very compressed under communism. Munich et. al. (op. cit.) put it thus:

"During a significant part of the twentieth century, over one-third of the world's population lived under the communist system. A large proportion of those who were in the labour force had their wages set according to a centrally determined wage grid. While the effects of the grid have never been formally analysed there has been a general perception that earnings structures in centrally planned economies were very compressed...", (Munich, Svejnar and Terrell, 1999).

The fact that the estimated wage returns to education under the old system were very low, see for instance Newell and Reilly (1999), seems to support this view. However, the estimated wage equations tended to fit the data quite poorly, see again Newell and Reilly (op. cit.). Studies of wage inequality give an entirely different picture. Flemming and Micklewright (1999) summarise an exhaustive study of income inequality in the transition countries as follows,

'... it was dangerous to generalise about income distribution in the socialist economies, especially in relation to market economies.... as far as the earnings of full-time workers are concerned, dispersion towards the end of the socialist period...matched that in several OECD economies...'

(Flemming and Micklewright, 1999).

The evidence suggests we cannot make firm predictions about the long-term direction of wage inequality, since OECD experience would have been our only reasonable guide. Economic theorising also seems unlikely to help us make such predictions, unless the preferences of communist planners could somehow be made endogenous. Recognising this, existing models of the wage distribution in transition, see Milanovic (1999) and Aghion and Commander (1999), resort to assuming the emerging private sector will feature greater wage dispersion than the state sector.

The dislocations of 'initial shock' in the early to mid-1990s caused an area-wide rise in income inequality. As before, we might usefully separate this period from the more gradual change in the distribution that will happen as the private sector emerges. 
Table 1 shows the progress of Gini coefficients for household income for seven transition countries 1989-1997. Among most countries, there has been increasing inequality through the 1990s. There is rising inequality in the late 1990s associated with economic growth in the Czech Republic, Hungary and Poland. In Bulgaria, Romania and Russia, macroeconomic stagnation has been associated with a levelling off of inequality. Table 2 gives measures of the variance of wages across industries. Though these data provide a very crude measure of inequality, they confirm the broad trend of rising wage inequality though the 1990s. Again, this is visible in the reviving East European economies of the late 1990s. Also again, in some of the former Soviet countries, where employment continued to fall through the late 1990s, the large initial rise in inequality steadied after 1993/4.

Milanovic (op. cit.) presents strong evidence that the most important factor in this near universal rise in household income inequality is rising inequality in wage income across households, see his table 6 (op. cit. p315) and table 8 (p319). This begs further clarification. Rising wage income inequality is (at least) a two-dimensional phenomenon. It can come about because of greater inequality of working hours across households and/or via rising hourly wage inequality ${ }^{\mathrm{i}}$.

The theoretical models of Milanovic and Aghion and Commander (op. cit.) do not distinguish between inequality in hourly wages and hours inequality. Perhaps a tacit assumption behind this choice is that hourly wage inequality is likely to be the main driving force behind income inequality in the longer term, whereas undesired rises in participation or hours inequality will be only transient features of economic restructuring ${ }^{\mathrm{ii}}$.

What do we take forward from this section? Firstly, it seems likely that the most reliable evidence on the long-term direction of inequality in transition will come from the reviving East European economies. Secondly a question is raised about the breakdown of the rise in wage inequality into hours and participation on the one hand and the hourly wage on the other hand. Existing studies for Poland, for instance, show relatively little movement in hourly wage inequality through the mid-1990s, see, inter alia, Newell and Socha (1998), Newell and Reilly (1999) and Newell and Reilly (2000). In section 4 we 
investigate the contributions of hours and hourly wages to changes in the distribution of Polish household labour income during the late 1990s. Thirdly, the data in table 2 suggest that the rise in inequality may partly derive from industrial and occupational restructuring. We draw a stylised picture of this restructuring in the next section and investigate its impact on Polish wages in section 4.

\section{3: The changing structure of labour markets.}

\section{1: The transition in employment by industry and occupation.}

I use the broadest of brushes, looking at the shares of agriculture, production industries and of services, see table 3 . The share of agriculture in employment has shown little average movement, either in East Europe or in the Former Soviet countries. This average hides wide diversity, though. In the more rapid growing countries such as the Czech Republic, Estonia, Hungary, Poland and Slovakia, agricultural employment has fallen rapidly. By contrast, in Bulgaria, Kyrgyzstan and Moldova the share of agriculture in employment has risen, suggesting that workers fell back on farming following heavy collapses of employment in mining and manufacturing. Macours and Swinnen (2000) analyse the decline in agricultural output in Central and Eastern Europe. They make it clear that, as we have seen at the national level, the movements in employment and output are not well correlated.

A falling share of employment in the production sector (mining, manufacturing and utilities) is a region-wide phenomenon caused by various forces. Firstly, it can be partly understood as a rise in the service sector. Employment in services, as table 3 shows, was comparatively low under communism. For example, see the line for Great Britain in table 3. A rise in service sector employment was highly predictable feature of transition. However, the initial shock undoubtedly created severe disruption to activity in the production sector, which would have, for instance, borne the heaviest blow from the destruction of communist trading patterns.

Turning to occupations in table 5, there is a visible increase in the share of nonmanual workers in much of the region. Underlying this trend are general increases in the shares of managerial, professional and technical workers, presumably reflecting the rise in the service sector. All the transition countries, especially Romania, have lower non- 
manual employment shares than the United Kingdom, see the last row of the table. Table 6 presents the evolution of the share of skilled manual, or craft, workers in total employment. In Estonia and Slovenia where longer series are available, the share is falling. Again, there has been a commensurate downward drift in the share of craft employment in the UK during the 1990s.

\section{2: The transition in wages by industry.}

Table 4 gives the wage in each industrial group, relative to the national average. Relative wages in agriculture have fallen almost everywhere and particularly so in the former Soviet countries. This is also consistent with the evidence for Eastern and Central Europe of Macours and Swinnen (2000). Turning to the production sector, despite fairly universal reductions in the share in total employment, relative wages in production have been maintained or improved in most countries. Service sector wages have risen a little overall, but this sector contains public services (education, health, public administration) as well as new private services. To highlight this heterogeneity, the last two columns show the path of relative wages in the financial, insurance and real estate sector, which have grown rapidly almost everywhere.

\section{3: Summary.}

In summary, there has been a rise in wage inequality, rising relative wages and employment in the service sector, falling employment and rising wages in the production sector and lastly, for agriculture, no overall trend in employment but strongly declining wages. By occupation, there has been a mild drift towards non-manual employment and away from skilled manual work, but these trends are no greater than in the United Kingdom.

Also we have established that, by and large, industrial change in employment and the variance of industrial wages were largest in countries where the decline of output has been largest. These seem likely to be the proximate causes of the outbreak of labour income inequality during the initial shock period. 
These are suggestive results. In the next section we narrow our focus to the study of the Polish Labour Force Survey to investigate:

1. the contributions of hourly wages and participation to the growth of household labour income inequality,

2. the impact of sectoral shifts, privatisation and unobserved heterogeneity on the wage distribution.

\section{4: The distribution of labour income in Poland.}

Household labour income inequality increased substantially in Poland from 1992. The first line of Table 7 gives Gini coefficients for household labour income, showing an increase from 1992 to 1994, falling back a little to 1997, the last year of the Polish labour Force Survey for which household was identified.

Household labour income per adult can be decomposed into the product of: hourly wages, hours per family worker and the household employment to adult population ratio. Chart 3 gives the Lorenz curves underlying the Gini coefficients for 1992 and 1997 . The chart suggests the rise in inequality is mostly a rise in the share of workless households. Changes in participation will be discussed in section 4.1 , but before that let us confirm that the wage distribution contributes little to the rise in inequality. Look at the distribution of per adult household labour income within the group of households who receive some labour income, in Table 7 . The 90/10 decile ratio actually contracted, with a small rise in the 90/50 decile ratio offset by a reduction in the 50/10 decile ratio. There were almost identical changes in the distribution of hourly wages across individuals. In the middle section of Table 7, we can see a decline in the 90/10 decile ratio for hourly wages. As with household labour income, this change is the product of a small increase in the 90/50 decile ratio and a reduction of the 50/10 ratio. The Gini coefficient for hourly wages contracted from 1992 to 1998 . In brief, household labour income became more unevenly distributed in Poland through the 1990, but this was not caused by increasing individual wage inequality did not cause this; in fact it decreased somewhat. 
The increase in workless households is discussed in section 4.1. Section 4.2 analyses the effects of privatisation and industrial change on the wage distribution.

\section{1: The decline in participation.}

Table 7 gives summary statistics of changes in household employment. First, it is clear the proportion of households with no labour income has risen between 1992 and 1997, from 27.1 percent to 28.8 percent. This is for three reasons. First, It seems that as young people are delaying the formation of new working households. We shall see they are staying much longer in education, and while they do so, they stay longer in their parents' households. This fall in the formation of new working households means that a higher proportion of the remaining households contain retired workers. Secondly, the population also grew a little older. The average age of those surveyed in the Polish Labour Force Survey (PLFS) rose from 42.8 in 1992 to 43.1 in 1998. However, the average age of heads of households in the PLFS grew from 49.6 to 51.2 over the same period. This massive increase is due to the later formation of young households, to be illustrated below, and to earlier retirement.

To illustrate the effects of these changes, look at the evolution of two-adult households. First, there was a decline in the share of two-adult households over the period, from 43.5 percent of all households to 41.8 percent. Clearly the destruction of such households outstripped the creation of new households. However, the share of twoadult households with both members over 55 and neither participating in the labour market rose from 7.8 percent to 9.2 percent of the household population. This rise (1.4 percentage points) accounts for almost the entire rise (1.7 percentage points) in the share non-employed households.

Secondly, the rise of the share of households without work is also reflected in the overall decline in individual participation in Poland during the period of economic recovery. Participation rates fell for all age groups between 1992 and 1998. The largest falls were among 15 to 24 year-olds, whose participation rate fell from 46.5 percent to 37.2 percent, and among over-55 year-olds, whose participation rate fell from 25.1 
percent to 22.5 percent. These two groups account for about two-thirds of the fall in participation.

The most dramatic change was among 20-24 year olds. In 1992 13.1\% of these were in full-time education and living in the parental home, whereas 24.2 percent had left education and formed new households. By 1998, the percentage still in education and living at home had risen to $20.8 \%$ while the share who had left education and set up their own home had dropped to $17.6 \%$. The decline in marital status among 20-24 year-olds reflects the trend towards later household formation. In 199239 percent of young adults were married. By 1998 this had fallen to $26 \%$. The trend to later household formation has by no means finished working its way through the population. The proportion of 19 year olds remaining in full-time education rose every year from 1992 to 1998.

This is a timely reminder that not all rises in cross-section inequality are bad. If young people take more full-time education, then cross-section inequality must rise in steady-state, even if there are no effects of the distribution of wages and thus no change in lifetime income inequality.

\section{2: The impact of privatisation and sectoral shifts on wages.}

Finally we investigate how, if at all, the transition has impacted on wages in Poland during the post-initial shock period. Table 8 compares the structure of employment and the degree of privatisation by industry between 1994 and 1998. 1994 is the earliest year for which the Polish Labour Force Survey incorporated internationally standard industrial and occupational codes. The shares of agriculture, mining and utilities all fall over the period, while the shares of construction, transport, finance and especially trades (retail and wholesale trade, hotels and restaurants) have all increased. Of the old 'production industries' only manufacturing has maintained its share of employment.

Privatisation has been dramatic. The private sector share of employees in employment increased from 25\% in 1994 to $40 \%$ in 1998, by which time manufacturing, trade and construction employment was mostly privatised. 


\section{(a) Privatisation.}

The variance of wages is larger in the private sector, though the gap is closing. In 1992 the variance of $\log$ wages in the private sector was $15 \%$ higher than in the public sector, but by 1998 this gap was only $1.7 \%$. Newell and Socha (1998), using the Polish Labour Force Survey, found that estimated private sector wage equations fitted less well than identical specifications estimated on public sector data. They interpreted this as demonstrating the greater importance of unobserved individual productivity characteristics for wage determination in the private sector.

In order to re-inspect this in the 1994 and 1998 data, I estimated identicallyspecified log hourly wage regressions for private and public sectors, by gender. Table 10 gives goodness of fit statistics for all eight regressions. It is clear in the 1994 data that the private sector wage regressions fit much less well than those for public sector pay. This is in line with previous findings. For 1998, however, after a great expansion of the private sector, there is no clear difference between goodness of fit statistics across sectors. Thus, though privatisation increased between 1994 and 1998, this seems not to be due to an increasing importance of unobserved productivity characteristics.

Table 9 reports estimates of education, industry, occupation, sector and location on log hourly wages for the 1994 and 1998. For education, it is noticeable that all coefficients rise between the two dates, and significantly so for secondary education. Note that controls for occupation are included, so the education coefficients reflect an impact on wages other than via sorting into broad occupational category. A test of the joint significance of the increases in the education coefficients gives an insignificant result $(\mathrm{t}=1.3)^{\mathrm{iii}}$.

The industries that grew over the period such as construction, trade, transport and finance receive often significantly increased wage premia, whereas in declining industries, such as mining and the utilities the premia fall significantly. By occupation, white-collar premia all rose, though none are individually significant. A test for the joint significance of the increases in the five white-collar premia yielded $t=2.6$. 
In summary, these result tells us that alongside falling wage inequality in Poland between 1994 and 1998 there has been a general increase in the wage returns to observable characteristics, improving the goodness of fit of wage regressions and reducing the residual variance. ${ }^{\text {iv }}$

\section{5: Conclusions.}

This paper has recorded the decline real wages and output in the initial shock period of transition. Employment also declined almost universally, but across countries, this was not correlated with changes in output. The most likely reason is the welldocumented tendency to labour hoarding, perhaps better understood as labour retention, especially in the former Soviet countries. The size of the initial shock is also associated with the scale of sectoral shifts in employment and rising inter-industry wage differentials. This combination of collapsing real wages, sectoral shifts in employment and increasing industrial wage diversity seem likely to be the main candidates for the general increase wage inequality during the initial shock period.

In Eastern Europe, where economic growth has restarted, there have been further increases in household income inequality. Taking the case of Poland, I have found this rise in inequality associated with an increased incidence of workless households associated with increased education participation, later household formation and earlier retirement. An increase in income inequality is a natural and entirely benign consequence of a movement to improved education levels. For Poland, the rise in household inequality is not related to increasing wage inequality among individual workers. Individual wage inequality actually fell in Poland, despite there having been increased wage premia to education, to growing sectors and regions in the economy and to senior occupations.

Of course it would be very interesting to repeat this work for other countries. 


\section{Bibliography}

Aghion, Philippe and Simon Commander (1999), "On the dynamics of inequality in the transition", Economics of Transition, 7, 2, 275-298.

Atkinson, Anthony B. and John Micklewright, (1992), Economic transformation in Eastern Europe and the distribution of income, Cambridge, Cambridge University Press.

Basu, Swati, Saul Estrin and Jan Svejnar, (2000), "Employment and wages in enterprises under communism and in transition; evidence from Central Europe and Russia", William Davidson Institute at the University of Michigan Working paper 114b, May.

Flemming, John and John Micklewright (1999), "Income distribution, economic systems and transition", Innocenti Occasional Papers, Economic and Social Policy Series, no. 70, Florence: UNICEF International Child Development Centre and Chapter 14 of A. B. Atkinson and F. Bourguignon (Eds.) Handbook of Income Distribution, Elsevier Science BV

Macours, K. and J. F. M. Swinnen (2000), "Causes of output decline in economic transition: the case of Central and Eastern European Agriculture", Journal of Comparative Economics, March 20, 1, 172-206.

Milanovic, Branco (1999), "Explaining the increase in inequality during transition", Economics of Transition, 7, 2, 299-341.

Munich, Daniel, Jan Svejnar and Katherine Terrell (1999), "Returns to human capital under the communist wages grid and during the transition to a market economy", Journal of Comparative Economics, 27, 33-60.

Newell, Andrew and Barry Reilly, (1996), "The gender wage gap in Russia: some empirical evidence", Labour Economics, 3, 3, 337-356.

Newell, Andrew and Barry Reilly, (1999) "Rates of return to educational qualifications in the transitional economies", Education Economics, 7, 1.

Newell, Andrew and Barry Reilly (2000) "The gender wage gap in the transition from communism", William Davidson Institute, University of Michigan, Working Paper No. 305, forthcoming in Economic Systems.

Newell, Andrew and Mieczslaw Socha (1998) "The roles of privatisation and changes in international trade in changes in the distribution of wages in Poland 1992-1996", Economics of Transition, 6, 1. 
Orazem, Peter, F. and Milan Vodopivec (1995), "Winners and Loses in Transition: Returns to Education, Experience and Gender in Slovenia", World Bank Economic Review, 9, 2, 201-230.

Rutkowski, Jan, (1996), "High Skills Pay Off: The Changing Wage Structure During Economic Transition in Poland", Economics of Transition, 4, 1, 89-111.

UNICEF (1999), Women in Transition, The MONEE Project, CEE/CIS/Baltics, Regional Monitoring Report No. 6, Florence, UNICEF.

Vercernik, Jiri, (1995), "Changing Earnings Distribution in the Czech Republic: Survey Evidence from 1988-1994", Economics of Transition, 3, 3, 355-371.

White, H (1980), "A Heteroscedasticity-Consistent Covariance Matrix Estimator and a Direct Test for Heteroscedasticity, " Econometrica, 48, 1980, 817-838. 
Chart 1:Changes in real wages and output 1989-1998.

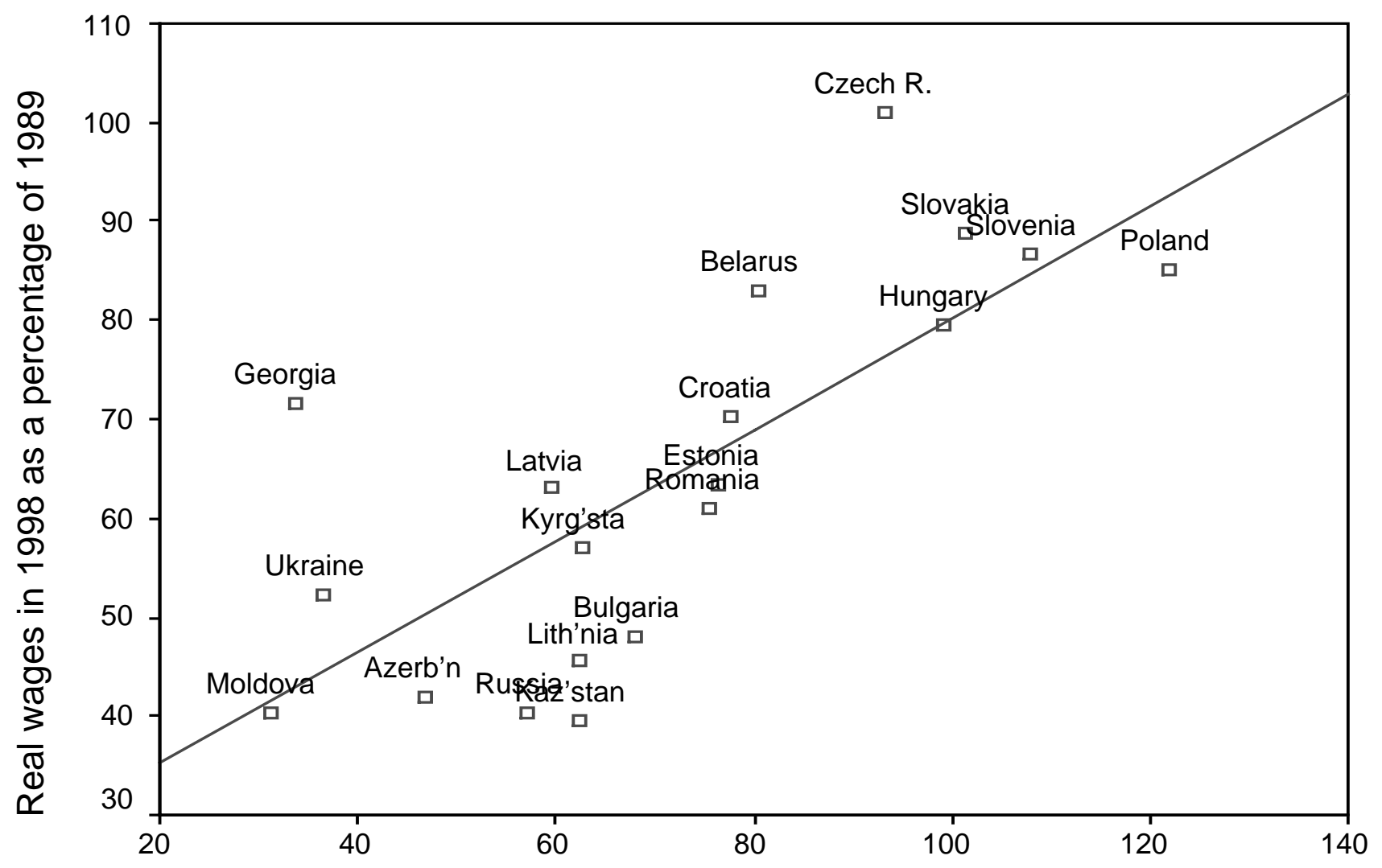

GDP in 1998 as a percentage of 1989 
Chart 2: Changes in employment and GDP 1989-1998

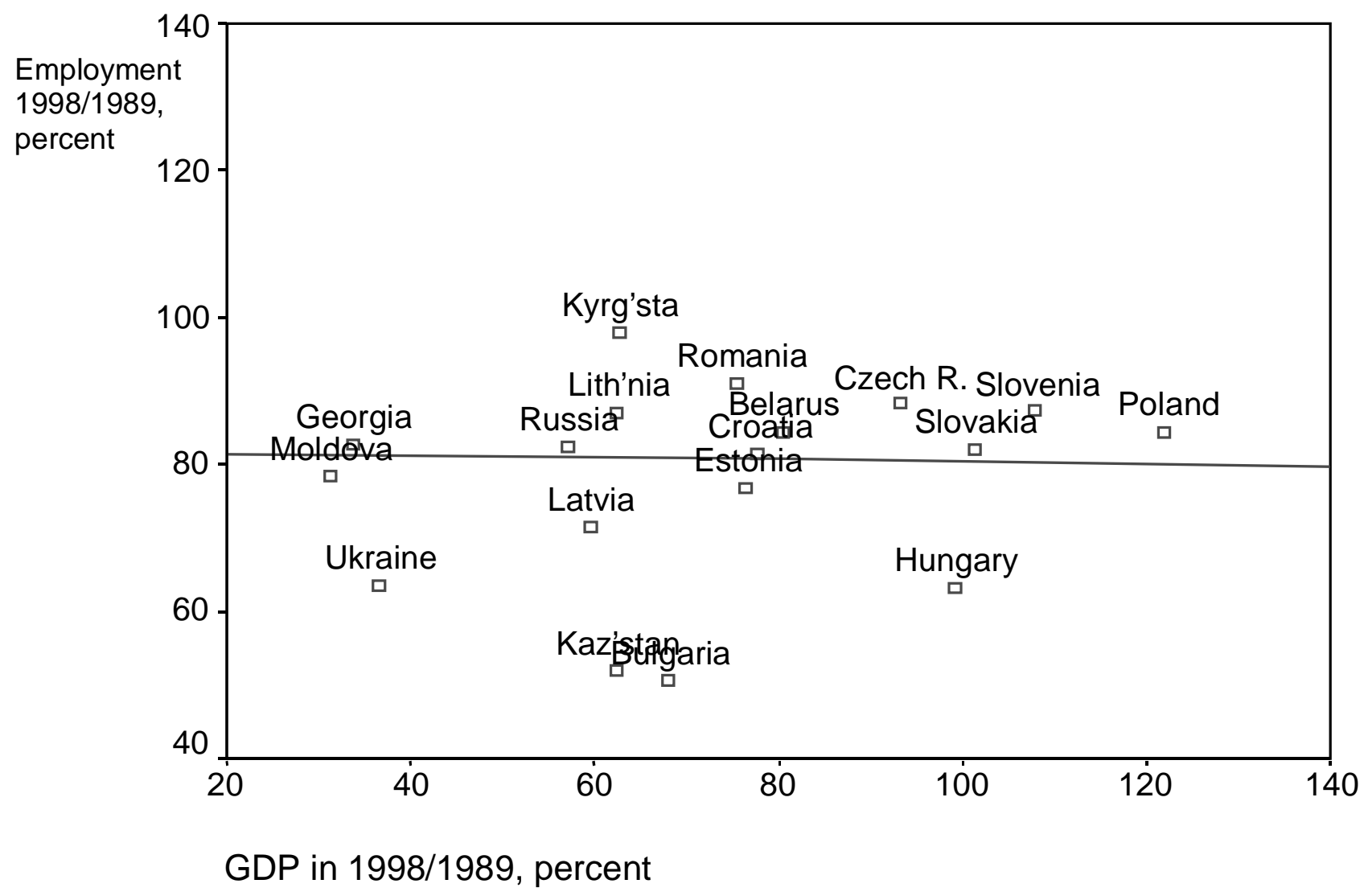


Chart 3: Lorenz curves for monthly household labour income, Poland 1992 and 1997

Source: Polish Labour Force Survey.

Key: solid line, represents November 1992, dashed line represents November 1997

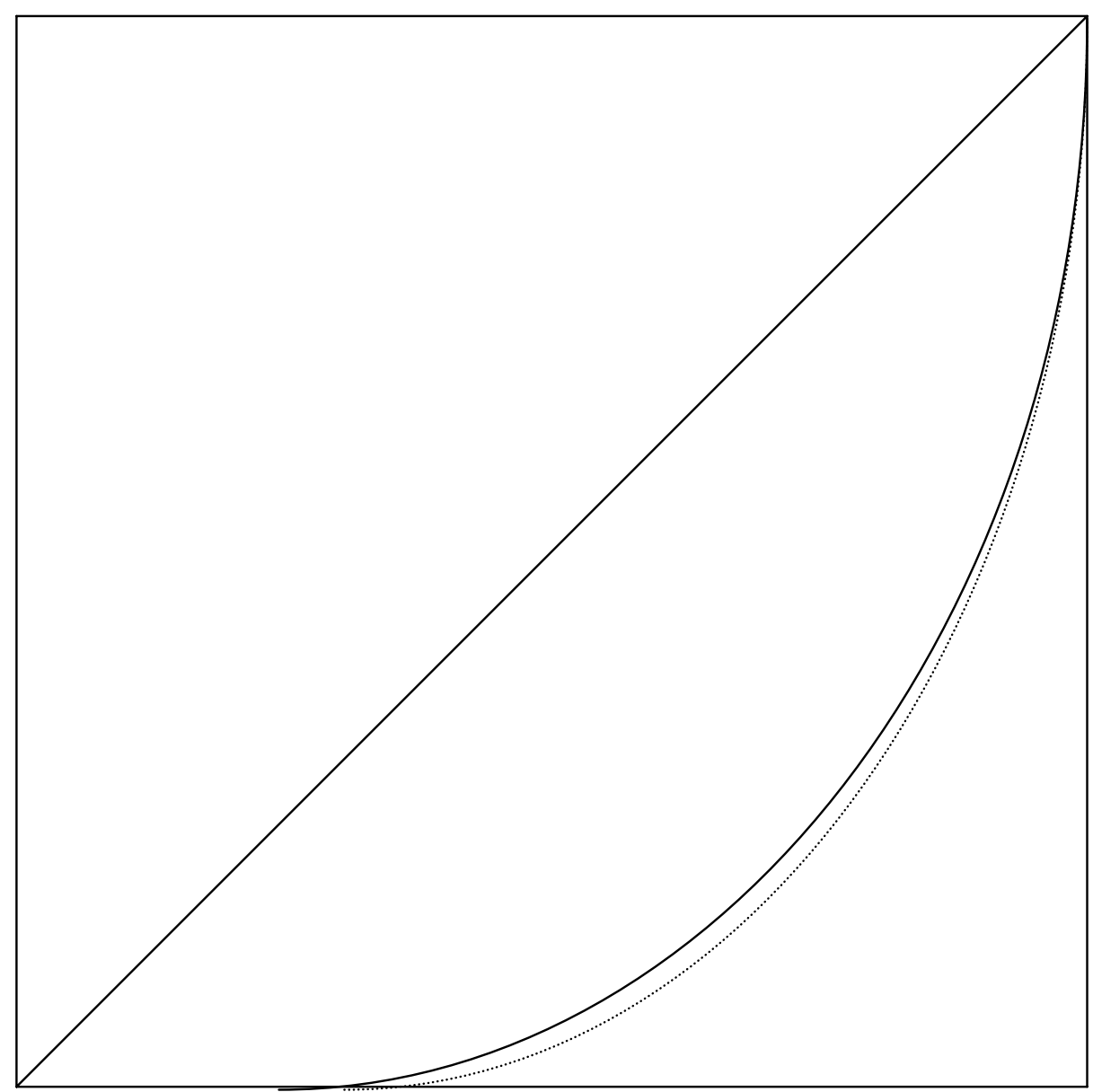


Table 1 Income inequality: Gini coefficents

\begin{tabular}{llllllllll}
\hline Year & 1989 & 1990 & 1991 & 1992 & 1993 & 1994 & 1995 & 1996 & 1997 \\
\hline Bulgaria &. &. &. & 0.331 & 0.335 & 0.374 & 0.384 & 0.357 & 0.366 \\
Czech Republic & 0.198 & 0.190 &. & 0.215 & 0.214 & 0.230 & 0.216 & 0.230 & 0.239 \\
Hungary & 0.225 &. & 0.209 &. & 0.231 & 0.234 & 0.242 & 0.246 & 0.254 \\
Poland & 0.275 & 0.268 & 0.265 & 0.274 & 0.317 & 0.323 & 0.321 & 0.328 & 0.334 \\
Romania & 0.237 & 0.227 & 0.258 & 0.259 & 0.267 & 0.264 & 0.306 & 0.302 & 0.305 \\
Russia & 0.265 & 0.236 & 0.257 & 0.363 & 0.381 & 0.405 & 0.385 &. &. \\
Slovenia &. &. & 0.265 & 0.259 & 0.320 & 0.246 & 0.264 & 0.252 &. \\
\hline
\end{tabular}

Source:UNICEF (1999), Table 10.13, page 144.

Table 2: The coefficient of variation of industrial wages*

\begin{tabular}{|c|c|c|c|}
\hline Year & $1989-90$ & 1993-94 & $1997-98$ \\
\hline Bulgaria & 0.10 & 0.28 & 0.27 \\
\hline Croatia & 0.19 & 0.14 & . \\
\hline Czech R. & . & 0.15 & 0.23 \\
\hline Hungary & . & 0.21 & 0.23 \\
\hline Romania & . & 0.16 & 0.36 \\
\hline Slovakia & . & 0.15 & 0.33 \\
\hline Eastern Europe & . & 0.18 & 0.28 \\
\hline Azerbaijan & 0.27 & 0.60 & 0.61 \\
\hline Belarus & 0.18 & 0.41 & . \\
\hline Estonia & 0.19 & 0.43 & . \\
\hline Latvia & . & 0.35 & 0.28 \\
\hline Kazakhstan & 0.21 & 0.43 & 0.33 \\
\hline Kyrgyzstan & 0.18 & 0.31 & 0.37 \\
\hline Moldova & 0.23 & 0.34 & \\
\hline Russia & 0.22 & 0.44 & 0.40 \\
\hline Former Soviet & 0.21 & 0.41 & 0.40 \\
\hline \multicolumn{4}{|l|}{ Reference item: } \\
\hline Great Britain & 0.22 & 0.21 & 0.24 \\
\hline
\end{tabular}

Source: author's calculations using ILO data from: http://laborsta.ilo.org/.

* Data on wages by industry are combined into seven industrial categories for comparison. The seven categories are: agriculture, production, construction, trade, transport, finance and real estate, and other services. 
Table 3: Percentage shares of employment by industry in 1989 and $1998^{1}$.

\begin{tabular}{lcccccccc}
\hline & \multicolumn{2}{c}{ Agriculture } & \multicolumn{2}{c}{ Production } & Public Services & \multicolumn{2}{c}{ All services } \\
\hline Bulgaria & 1989 & 1998 & 1989 & 1998 & 1989 & 1998 & 1989 & 1998 \\
Croatia & 18.7 & 25.7 & 37.7 & 26.4 & 18.4 & 21.2 & 43.6 & 47.9 \\
Czech Republic & 5.0 & 4.6 & 38.4 & 33.1 & 20.1 & 24.4 & 56.8 & 62.3 \\
Hungary & 8.7 & 5.9 & 41.2 & 38.6 & 22.8 & 23.3 & 50.1 & 55.5 \\
Romania & 11.3 & 7.5 & 29.7 & 28.0 & 25.5 & 27.4 & 59.0 & 64.5 \\
Slovakia & 9.6 & 6.4 & 47.1 & 43.6 & 14.8 & 17.6 & 43.3 & 49.9 \\
Eastern Europe & 15.0 & 8.9 & 32.8 & 34.2 & 20.5 & 29.9 & 47.1 & 56.9 \\
& $\mathbf{1 1 . 4}$ & $\mathbf{9 . 8}$ & $\mathbf{3 7 . 8}$ & $\mathbf{3 4 . 0}$ & $\mathbf{2 0 . 4}$ & $\mathbf{2 4 . 0}$ & $\mathbf{5 0 . 1}$ & $\mathbf{5 6 . 2}$ \\
Azerbaijan & & & & & & & & \\
Estonia & 31.6 & 29.3 & 20.6 & 9.9 & 22.9 & 31.1 & 47.8 & 60.8 \\
Kazakstan & 20.1 & 7.1 & 29.9 & 27.4 & 20.5 & 27.0 & 48.6 & 63.6 \\
Kyrgyzstan & 21.9 & 17.3 & 21.0 & 22.1 & 30.3 & 36.7 & 57.1 & 60.6 \\
Russia & 33.2 & 48.7 & 16.5 & 6.1 & 29.1 & 26.5 & 50.2 & 45.2 \\
Former Soviet & 13.9 & 14.2 & 29.4 & 22.6 & 21.1 & 25.0 & 56.4 & 63.0 \\
Reference item & $\mathbf{2 4 . 1}$ & $\mathbf{2 3 . 3}$ & $\mathbf{2 3 . 5}$ & $\mathbf{1 7 . 6}$ & $\mathbf{2 4 . 8}$ & $\mathbf{2 9 . 3}$ & $\mathbf{5 2 . 0}$ & $\mathbf{5 8 . 7}$ \\
Great Britain & & & & & & & & \\
\hline Source: auth & 1.4 & 1.3 & 23.2 & 18.4 & 28.6 & 29.8 & $\mathbf{7 5 . 4}$ & 81.0 \\
\hline
\end{tabular}

Source: author's calculations using ILO data from: http://laborsta.ilo.org/.

In this table, agriculture refers to agriculture, forestry and fishing; production includes mining, manufacturing and energy; services includes financial and real estate, public and other services, construction, trade and transport.

${ }^{1}$ the first date is 1989, except for: Czech Republic (1993), Hungary (1992), Latvia (1992), Romania (1993), Russia (1990) and Slovakia (1991). The second date is 1998, except for Croatia (1996), Moldova (1994), Estonia, Romania, Russia and Slovakia, all (1997). 
Table 4: Relative wages by industry in 1989 and $1998^{*}$.

(Each cell gives the ratio of the sector average wage to the national average wage)

\begin{tabular}{lcccccccc}
\hline & \multicolumn{2}{c}{ Agriculture } & \multicolumn{2}{c}{ Production } & \multicolumn{2}{c}{ Services } & \multicolumn{2}{c}{ FIRE } \\
\hline & 1989 & 1998 & 1989 & 1998 & 1989 & 1998 & 1989 & 1998 \\
\hline Bulgaria & 0.97 & 0.89 & 1.00 & 1.14 & 0.91 & 0.88 & 1.11 & 1.61 \\
Croatia & 0.94 & 1.01 & 0.94 & 0.94 & 1.18 & 1.08 & 1.28 & 1.28 \\
Czech Republic & 0.88 & 0.79 & 1.01 & 1.01 & 1.02 & 1.11 & 1.27 & 1.78 \\
Hungary & 0.69 & 0.99 & 0.72 & 1.03 & 1.12 & 1.03 & 1.41 & 1.42 \\
Romania & 0.85 & 0.74 & 1.02 & 1.10 & 0.93 & 0.97 & 1.13 & 1.77 \\
Slovakia & 1.00 & 0.80 & 1.01 & 1.03 & 1.02 & 1.11 & 1.06 & 1.94 \\
Eastern Europe & $\mathbf{0 . 8 9}$ & $\mathbf{0 . 8 7}$ & $\mathbf{0 . 9 5}$ & $\mathbf{1 . 0 4}$ & $\mathbf{1 . 0 3}$ & $\mathbf{1 . 0 3}$ & $\mathbf{1 . 2 1}$ & $\mathbf{1 . 6 3}$ \\
& & & & & & & & \\
Azerbaijan & 1.05 & 0.63 & 1.45 & 3.19 & & & 1.28 & 4.75 \\
Belarus & 0.96 & 0.65 & 1.11 & 1.23 & 0.86 & 0.89 & 0.99 & 2.19 \\
Estonia & 1.11 & 0.73 & 1.86 & 1.05 & 0.82 & 1.22 & 0.91 & 2.03 \\
Kazakstan & 1.03 & 0.67 & 1.15 & 1.28 & & & 0.87 & 4.39 \\
Kyrgyzstan & 0.90 & 0.48 & 1.23 & 1.30 & 0.86 & 0.76 & 1.06 & 1.30 \\
Moldova & 0.92 & 0.72 & 1.14 & 1.34 & 0.81 & 1.07 & 1.03 & 2.13 \\
Russia & 0.85 & 0.74 & 1.02 & 1.10 & 0.97 & 1.06 & 1.40 & 1.83 \\
Former Soviet & $\mathbf{0 . 9 7}$ & $\mathbf{0 . 6 6}$ & $\mathbf{1 . 2 7}$ & $\mathbf{1 . 5 0}$ & $\mathbf{0 . 8 6}$ & $\mathbf{1 . 0 0}$ & $\mathbf{1 . 0 8}$ & $\mathbf{2 . 6 6}$ \\
Reference item: & & & & & & & & \\
Great Britain & 0.60 & 0.63 & 0.97 & 0.97 & 1.13 & 1.19 & 1.24 & 1.21 \\
\hline Source: auther s & & & & & &
\end{tabular}

Source: author's calculations using ILO data from: http://laborsta.ilo.org/.

In this table, agriculture refers to agriculture, forestry and fishing; production includes mining, manufacturing and energy; services includes financial and real estate, public and other services, construction, trade and transport. FIRE refers to finance, insurance and real estate.

*the first date is 1989, except for: Czech Republic (1993), Hungary (1992), Latvia (1992), Romania (1993), Russia (1990) and Slovakia (1991). The second date is 1998, except for Croatia (1996), Moldova (1994), Estonaia, Romania, Russia and Slovakia, all (1997). 
Table 5: The percentage share of non-manual workers in total employment

\begin{tabular}{|c|c|c|c|c|c|c|c|c|}
\hline & 1991 & 1992 & 1993 & 1994 & 1995 & 1996 & 1997 & 1998 \\
\hline Croatia & & & & & & 50 & 52 & 54 \\
\hline Czech Republic & & & 51 & 44 & 53 & 53 & 54 & \\
\hline Hungary & & & & & 51 & 52 & 52 & 53 \\
\hline Poland & & & & & 43 & 43 & 44 & 46 \\
\hline Romania & & & & 26 & 26 & 28 & 28 & 27 \\
\hline Slovakia & & & & 51 & 53 & 52 & 53 & 53 \\
\hline Slovenia & & & 51 & 52 & 51 & 53 & 51 & 51 \\
\hline Estonia & 47 & 48 & 50 & 51 & 53 & 54 & 53 & 54 \\
\hline Latvia & & & & & 49 & 48 & 46 & 48 \\
\hline Russia & & & & & & & 51 & 51 \\
\hline United Kingdom & 65 & 66 & 67 & 68 & 68 & 69 & 70 & 70 \\
\hline
\end{tabular}

Source: author's calculations from ILO data from: http://laborsta.ilo.org/.

Table 6: The percentage share of craft workers in total employment

\begin{tabular}{|c|c|c|c|c|c|c|c|c|}
\hline & 1991 & 1992 & 1993 & 1994 & 1995 & 1996 & 1997 & 1998 \\
\hline Croatia & & & & & & 13 & 14 & 12 \\
\hline Czech Republic & & & 21 & 19 & 21 & 21 & 21 & \\
\hline Hungary & & & & & 23 & 22 & 22 & 23 \\
\hline Poland & & & & & 20 & 19 & 19 & 19 \\
\hline Romania & & & & 19 & 18 & 18 & 17 & 19 \\
\hline Slovakia & & & & 21 & 21 & 20 & 20 & 21 \\
\hline Slovenia & & & 14 & 14 & 14 & 14 & 13 & 11 \\
\hline Estonia & 22 & 21 & 20 & 20 & 19 & 18 & 17 & 17 \\
\hline Latvia & & & & & 15 & 15 & 15 & 15 \\
\hline Russia & & & & & & & 17 & 17 \\
\hline United Kingdom & 15 & 14 & 13 & 13 & 13 & 12 & 12 & 12 \\
\hline
\end{tabular}

Source: author's calculations from ILO data from: http://laborsta.ilo.org/. 
Table 7: The distribution of household and individual labour income in Poland 1992 and $1997 / 1998$.

\begin{tabular}{lccc}
\hline & 1992 & 1994 & 1997 \\
\hline Gini index for household labour income & 0.552 & 0.602 & 0.584 \\
& & & \\
Household distribution of employment & & & \\
Share without adult workers & 27.2 & 29.0 & 28.8 \\
Share in which all adults work & 26.3 & 23.2 & 23.1 \\
2-adult households (\%) & 43.5 & 44.8 & 41.8 \\
2-adult households with no employment (\%) & 11.9 & 13.7 & 13.2 \\
2-adult households with no employment and both over 55 & 7.8 & 9.2 & 9.2 \\
years & & &
\end{tabular}

(b) Among households with recorded labour income, per adult household income:

$\begin{array}{lccc}\text { 90/10 decile ratio } & 4.39 & 4.28 & 4.17 \\ \text { 90/50 decile ratio } & 2.08 & 2.09 & 2.08 \\ \text { 50/10 decile ratio } & 2.11 & 2.05 & 2.00 \\ \text { Gini index } & 0.338 & 0.338 & 0.339 \\ & & & \\ & 1992 & \mathbf{1 9 9 4} & \mathbf{1 9 9 8} \\ \text { Invididual participation rates (\%) } & & & \\ \text { Aged 15+ } & 61.1 & 58.0 & 55.4 \\ \text { Aged 15-24 } & 46.5 & 46.8 & 37.2 \\ \text { Aged 55+ } & 25.1 & 22.5 & 22.5\end{array}$

Individual hourly wages

$\begin{array}{lccc}\text { 90/10 decile ratio } & 3.11 & 3.00 & 2.89 \\ 90 / 50 \text { decile ratio } & 1.87 & 1.89 & 1.90 \\ 50 / 10 \text { decile ratio } & 1.66 & 1.58 & 1.52 \\ \text { Gini } & 0.262 & 0.255 & 0.247\end{array}$

Average hours per worker

$39.1 \quad 40.1 \quad 40.8$

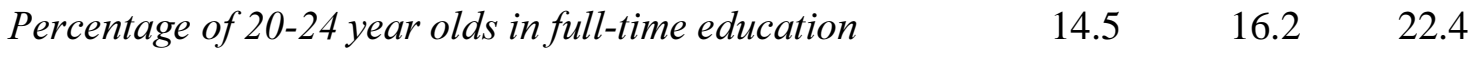

Percentage of 20-24 year olds married $\quad 39 \quad 33 \quad 26$

Source: author's calculations from the Polish Labour Force Survey.

${ }^{1}$ difference significant at the one percent level. 
Table 8: Industrial change and privatisation in Poland 1994-1998

\begin{tabular}{|c|c|c|c|c|}
\hline \multirow[b]{2}{*}{ Industry } & \multicolumn{2}{|c|}{1994} & \multicolumn{2}{|c|}{1998} \\
\hline & $\begin{array}{c}\text { Share of } \\
\text { employment } \\
\%\end{array}$ & $\begin{array}{c}\text { Employee } \\
\text { share \% in } \\
\text { private sector }\end{array}$ & $\begin{array}{c}\text { Share of } \\
\text { employment } \\
\%\end{array}$ & $\begin{array}{c}\text { Employee } \\
\text { share \% in } \\
\text { private sector }\end{array}$ \\
\hline Agriculture & 25.5 & 15.4 & 21.3 & 37.7 \\
\hline Mining & 3.0 & 3.2 & 2.3 & 7.0 \\
\hline Manufacturing & 20.8 & 36.7 & 20.5 & 59.7 \\
\hline Utilities & 1.7 & 8.4 & 1.6 & 16.4 \\
\hline Construction & 5.7 & 58.2 & 7.0 & 76.1 \\
\hline Trade & 12.7 & 58.3 & 15.1 & 80.5 \\
\hline Transport & 5.3 & 10.9 & 5.9 & 20.4 \\
\hline Finance & 3.7 & 17.9 & 5.0 & 33.9 \\
\hline Public and other services & 21.4 & 5.1 & 21.3 & 6.1 \\
\hline
\end{tabular}

Source: author's calculations from the Polish Labour Force Survey. 
Table 9: Modelling log hourly wages

\begin{tabular}{|c|c|c|c|}
\hline & $\begin{array}{c}\text { November } \\
1994\end{array}$ & $\begin{array}{c}\text { November } \\
1998\end{array}$ & $\begin{array}{c}\Delta \\
1998-1994\end{array}$ \\
\hline \multicolumn{4}{|l|}{$\begin{array}{l}\text { Completed education level } \\
\text { (default: primary or less) }\end{array}$} \\
\hline University & $0.412 * *$ & $0.416^{* *}$ & 0.004 \\
\hline Post secondary & $0.172 * *$ & $0.184 * *$ & 0.012 \\
\hline Vocational secondary & $0.143 * *$ & $0.180 * *$ & $0.037 *$ \\
\hline General secondary & $0.124 * *$ & $0.151 * *$ & $0.027 *$ \\
\hline Lower vocational & $0.060 * *$ & $0.074 * *$ & 0.014 \\
\hline \multicolumn{4}{|c|}{ Industry (default: public services) } \\
\hline Agriculture & $-0.079 * *$ & $-0.036^{*}$ & 0.043 \\
\hline Mining & $0.407 * *$ & $0.345 * *$ & $-0.062 * *$ \\
\hline Manufacturing & $0.019 *$ & $0.046^{* *}$ & $0.027 *$ \\
\hline Utilities & $0.244 * *$ & $0.194 * *$ & $-0.050 *$ \\
\hline Construction & $0.029 *$ & $0.099 * *$ & $0.070 * *$ \\
\hline Trade & -0.015 & $0.033 * *$ & $0.048 * *$ \\
\hline Transport & $0.050 * *$ & $0.088 * *$ & $0.038 *$ \\
\hline Finance, insurance etc. & $0.094 * *$ & $0.111 * *$ & 0.017 \\
\hline \multicolumn{4}{|c|}{ Occupation (default: skilled manual) } \\
\hline Managerial & $0.295 * *$ & $0.377 * *$ & 0.082 \\
\hline Professional & $0.120 * *$ & $0.214 * *$ & 0.094 \\
\hline Technical & $0.126 * *$ & $0.161 * *$ & 0.035 \\
\hline Clerical & 0.028 & $0.087 * *$ & 0.059 \\
\hline Sales & -0.030 & -0.019 & 0.011 \\
\hline Semi-skilled manual & 0.031 & 0.054 & 0.023 \\
\hline Unskilled manual & $-0.128 * *$ & $-0.071 *$ & 0.057 \\
\hline \multicolumn{4}{|l|}{ Firm size (default $>100)$} \\
\hline Under 6 employees & $-0.173 * *$ & $-0.145^{* *}$ & \\
\hline 6 to 20 employees & $-0.109 * *$ & $-0.098 * *$ & \\
\hline 20 to 50 employees & $-0.073 * *$ & $-0.057 * *$ & \\
\hline 50 to 100 employees & $-0.069 * *$ & $-0.041 * *$ & \\
\hline Warsaw & $0.174 * *$ & $0.206 * *$ & \\
\hline Western border counties & $0.026 * *$ & $0.036 * *$ & \\
\hline Private sector & $0.129 * *$ & $0.085 * *$ & \\
\hline Adjusted R-sq & 0.424 & 0.446 & \\
\hline Heteroskedasticity $\chi^{2}(1)$ & 15.0 & 14.6 & \\
\hline s.e.e. & 0.3109 & 0.2938 & \\
\hline$N$ & 15608 & 15000 & \\
\hline
\end{tabular}




\section{Notes to Table 9}

Method of Estimation: Ordinary Least Squares, standard errors calculated using White's (1980) Heteroscedasticity-consistent covariance matrix.

Additional variables in both models were: Potential experience and its square, tenure and its square, presence of disability, gender, marital status, relation to head of household and number of spells of unemployment since 1990.

$*$ and ** indicate significance at the 5 percent and 1 percent levels.

Data samples are all full-time employees in the relevant sweeps of the Polish Labour

Force Survey.

Table 10: Goodness of fit (Adjusted $\mathrm{R}^{2}$ ) statistics for log hourly wage regressions

\begin{tabular}{lcc}
\hline & 1994 & 1998 \\
\hline Public sector & & \\
$\quad$ Women & 0.428 & 0.444 \\
$\quad$ Men & 0.432 & 0.437 \\
Private sector & & \\
$\quad$ Women & 0.336 & 0.463 \\
Men & 0.352 & 0.422 \\
\hline
\end{tabular}

Notes to table 10

Sample and Method: see table 9.

The estimating equations were specified are as the equation in Table 9, except that a full set of county (voivodship) dummies were included in place of the regional variables.

\section{Endnotes}

${ }^{\mathrm{i}}$ In the context of many of the former Soviet countries, the existence of wage arrears demands a further decomposition.

${ }^{i i} \mathrm{OF}$ course the transition may well bring about desired changes in participation and hours. For example, the high participation rate of women in full-time employment under communism seems unlikely to remain.

iii Very similar results are obtained even if occupation indicators are omitted from the equation.

iv Of course, the variance of log wages is not many people's preferred measure of wage inequality. An approximate decomposition of the hourly wage Gini coefficient into fitted and residual components gives a broadly consist picture. 


\section{IZA Discussion Papers}

\section{No Author(s)}

181

E. Wasmer

Y. Zenou

182 M. Fertig

C. M. Schmidt

183 M. Fertig

C. M. Schmidt

184 M. Corak

B. Gustafsson

T. Österberg

185 H. Bonin

K. F. Zimmermann

186

C. Dustmann

187
T. K. Bauer
M. Lofstrom
K. F. Zimmermann

188
A. Kapteyn
A. S. Kalwij
A. Zaidi

189

W. Arulampalam

190

C. Dustmann

I. Preston

191

192

G. C. Giannelli

C. Monfardini

193 A. Kunze

F. Pastore

G. Brunello

F. Büchel

A. Mertens

Titel

Area

Date

Space, Search and Efficiency

2

$8 / 00$

Discretionary Measures of Active Labor Market Policy: The German Employment Promotion Reform in Perspective

Aggregate-Level Migration Studies as a Tool for 1 Forecasting Future Migration Streams

Intergenerational Influences on the Receipt of 3 Unemployment Insurance in Canada and Sweden

The Post-Unification German Labor Market

4

$8 / 00$

Temporary Migration and Economic Assimilation

$8 / 00$

Immigration Policy, Assimilation of Immigrants and Natives' Sentiments towards Immigrants: Evidence from 12 OECD-Countries

The Myth of Worksharing

5

$8 / 00$

Is Unemployment Really Scarring? Effects of

3

$8 / 00$

Unemployment Experiences on Wages

Racial and Economic Factors in Attitudes to

Immigration

$8 / 00$

Joint Decisions on Household Membership and Human Capital Accumulation of Youths: The role of expected earnings and local markets

$8 / 00$

Absolute Risk Aversion and the Returns to

5

$8 / 00$ Education

The Determination of Wages and the Gender Wage Gap: A Survey

Restructuring in Poland

Overeducation, Undereducation, and the Theory of Career Mobility 
198 M. Kreyenfeld

A Forgotten Issue: Distributional Effects of Day 
212 X. Gong

A. van Soest

P. Zhang

213 X. Gong

A. van Soest

E. Villagomez

214 X. Gong

A. van Soest

215 J. Ermisch

M. Francesconi

216 F. Büchel

217

J. Hansen

R. Wahlberg

218 C. Dustmann

A. van Soest

219 F. Kramarz

T. Philippon

220 W. A. Cornelius

E. A. Marcelli

221

C. Grund

222 W.P.M. Vijverberg

223 M. Rosholm

M. Svarer

J. Schwarze

225

L. Modesto

J. P. Thomas
Sexual Bias and Household Consumption: A

Mobility in the Urban Labor Market: A Panel Data 1

The Effect of Parents' Employment on Children's

The Effects of Overeducation on Productivity in Variables

The Impact of Differential Payroll Tax Subsidies on 5 Minimum Wage Employment United States: New Evidence from California and Mexico

Wages as Risk Compensation in Germany 

former Soviet Union to Israel: Who is coming when?

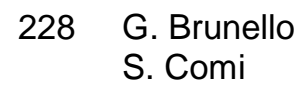

C. Lucifora

229 R. Coimbra

T. Lloyd-Braga

L. Modesto

230 L. Modesto

231

G. Saint-Paul

232

E. Bardasi

M. Francesconi

233

C. Dustmann

C. M. Schmidt

234

R. Rotte

M. Steininger

235

W. Schnedler

236
R. Hujer
M. Caliendo

237 S. Klasen

I. Woolard

238 R. Euwals

A. Börsch-Supan

A. Eymann

239 F. Andersson

K. A. Konrad

240

W. Koeniger
The College Wage Gap in 10 European and Earnings: An Empirical Study for Portugal Wahlerfolge in Deutschland: Das Beispiel der Europawahlen 1994 und 1999

Who gets the Reward? An Empirical Exploration of Bonus Pay and Task Characteristics

Evaluation of Active Labour Market Policy: 

Soviet Union: A Study of the Suicide Epidemic in the 1990s

244 S. M. Fuess, Jr. M. Millea

T. J. Hatton

J. G. Williamson

251

R. Yemtsov

252

R. Yemtsov

254 H. Gersbach

A. Schniewind

255 H. Gersbach

A. Schniewind

T. Boeri

H. Brücker

Pay and Productivity in a Corporatist Economy: 
258 M. Rosholm

The Times They Are A-Changin':

K. Scott

Organizational Change and Immigrant

L. Husted

Employment Opportunities in Scandinavia

259 A. Ferrer-i-Carbonell

Poverty in the Russian Federation

4

02/01

B. M.S. van Praag

260

P. Cahuc

F. Postel-Vinay

Temporary Jobs, Employment Protection and

$1 / 3$

$02 / 01$

261 M. Lindahl

Home versus School Learning:

5

$02 / 01$

A New Approach to Estimating the Effect of Class

Size on Achievement

262 M. Lindahl

Summer Learning and the Effect of Schooling:

5

$02 / 01$

Evidence from Sweden

263 N. Datta Gupta

Children and Career Interruptions:

5

$02 / 01$

N. Smith

The Family Gap in Denmark

264

C. Dustmann

Return Migration, Wage Differentials, and the

1

$02 / 01$

Optimal Migration Duration

265 M. Rosholm

Structurally Dependent Competing Risks

$02 / 01$

M. Svarer

266 C. Dustmann

The Optimal Migration Duration and Activity

O. Kirchkamp

Choice after Re-migration

267 A. Newell

The Distribution of Wages in Transition Countries

03/01

An updated list of IZA Discussion Papers is available on the center's homepage www.iza.org. 